\title{
A Culture of Israel Education
}

\begin{abstract}
Israel education is rooted in a cultural approach, which focuses on the role of social contexts and dynamics in education. Immersive environments are settings, which can influence attitudes by virtue of their synergistic nature. Connectedness refers to social linkages created by social networks. Virtual communities offer opportunities for enhancing an immersive approach to Israel education. The Israel experience is a significantly new Jewish educational framework. As in all education, the educator is a seminal force in the realization of the educational vision.
\end{abstract}

Keywords Connectedness • Immersive $\bullet$ Oeuvres $\bullet$ Virtual communities - The Israel experience

The relational approach to Israel education is rooted in two educational perspectives, sometimes regarded as contradictory, but which we regard as complementary - the humanist and the culturalist. The humanist approach teaches us that the person is the focus of education, and the culturalist approach teaches us that cultures are shaping forces of who we are and what we might become. A synergistic view of these two perspectives suggests an all-encompassing Israel education which is nourished by a culture, while, at the same time, focused on the person. Relational Israel education combines the learned-centered approach and the culturalist approach to create a holistic educational practice. Chapter 2 emphasized the interaction of the young with texts, narratives, and ideas related to Israel, then

(C) The Author(s) 2016 35

B. Chazan, A Philosophy of Israel Education, DOI 10.1007/978-3-319-30779-4_3 
and now. This chapter focuses on the creation of a socio-cultural framework for Israel education. We examine several ideas about culture and context as threads which when woven together form the tapestry that we call "a culture of Israel education".

\section{IMMERSIVE ENVIRONMENTS}

Consider how children ordinarily learn the ideas and values that are most cherished by their parents and their communities. Such learning takes place over time. It is not achieved through a specific course of instruction and is not affected in any one venue. It occurs through interaction with significant others who embody and are committed to such values. It is advanced through formative experiences that enable young people to actually participate in these ideas and values in their own lives. Being part of a community which shares these ideas and values is a unique experience. It is realized through opportunities to interact with peers and in order to better understand ideas, values, and behaviors.

Historically, this type learning occurred in families, local communities, and places of worship which together constituted holistic learning communities (Goitein 1999). These institutions were immersive environments where learning was advanced through conversation, practice, ritual, and relationships. The contemporary educational institutions that have come close to having such characteristics and achieving such outcomes are what sociologist Erving Goffman called "total institutions" (Goffman 1960). These are settings, such as boarding schools, army cadet programs, summer camps, or long-term retreats which can co-opt the full range of experiences in a day, a week, and a month to "speak" the language of the desired ideas and values. The chief characteristics of "total institutions" include the following: (1) all aspects of life are conducted in a similar place and under the same authority, (2) each phase of a member's life is carried out in the company of others, (3) all phases of the day's activities are tightly scheduled and sequenced, and (4) various activities are brought together in a single plan aimed at fulfilling the goals of the institution. For Goffman, the paradigmatic examples of total institutions were (ironically) prisons, convents, and mental hospitals, places that obviously don't offer the most desirable template for Israel education. At the same time, the notion of an immersive institution has much relevance for Israel education, and it is no coincidence that over the past 25 years, immersive educational frameworks of summer camps, retreats, educational travel 
programs, and the Israel experience have provided the Jewish community with the great hope for increased vitality (Soberman and Stewart 2015). These institutions are total or partial immersive environments where learning is advanced through setting, personnel, facilities, conversation, practice, ritual, and relationships, and they seem to have demonstrated a record of success. To be clear, the educational power of these programs derives not only from the amount of time, but more significantly from their immersiveness, from their capacity to submerge young people in a "total" experience. It suggests that, if we are to do better at achieving the multi-dimensional outcomes of Israel education, we need to more effectively utilize the full immersive capacity of our educational institutions.

In that sense, it can be said that Israel education should live in a broad totality of frameworks. It needs to totally permeate the lives of educational institutions: in mission statements, the consciousness of lay and professional leaders, formal and informal curricula, walls, halls, buses, music, holidays, and foods. Goffman believed that the non-verbal, non-cognitive, non-discursive elements of a culture are as important, or more so, for conveying cultural norms as the written word or the "classroom lesson." Numerous studies of unique school and other educational institutions across time and place echo this point ${ }^{1}$ (Bettelheim 1950; A.S. Neill 1970; Redl and Wineman 1957; Peshkin 1986).

There is a notion often indigenous to schooling that there are core contents and "subjects" which constitute "curriculum", and there are clubs, sports, hobbies, arts, and culture which are "extracurricular" or secondary activities that enrich and embellish. In fact, the reality may be just the opposite. Indeed, in Israel education, it is these "extras" that very often are the educational essence. Sometimes a song, a story, a person, a fable, a recipe, or a picture connected to Israel touches those thousands of neurons in the mind, which lead to feeling, thinking, and doing. The immersive approach to Israel education argues that the distinction between "extra" and "core" is not compelling, since people learn and are affected in diverse ways. Don't regard the fluff as extra trim; for some, it may be the entryway into the heart of the matter. Essentially, what is being suggested is that educators must learn to "think immersively". Thinking immersively involves a sophisticated approach to education, which calls upon educators to co-opt a totality of senses, foci, and resources. Educators need to be cognizant of the conditions that constitute the given framework (ideological or denominational affiliation, size of institution, architecture of the institution, staff), and they should 
co-opt them to highlight and upgrade the Israel immersion of the institution. The ideal situation occurs when all the components of an immersion experience integrate, but that doesn't always happen. Too often, educators are forced to become harried hosts of a smorgasbord that becomes messy and non-aesthetic. The challenge of immersive education is to turn the buffet of diverse foods into an aesthetic dining experience in which the various components enhance each other.

It might be argued that this is a manipulative picture for Israel education. It might, but it need not be. It certainly is true that techniques of immersiveness have been used for indoctrination, but there also are many instances when they are employed as educative forces. The key is to retain the core vision - the relationship with Israel-in mind. One might also argue that given the realities of contemporary Jewish life, this immersive idea is simply too difficult to implement. Indeed, contemporary realities of Jewish life would seem to argue just the opposite; that is, these immersive activities are reported as life changing rather than the normal nonimmersive structure of Jewish education.

\section{Connectedness}

In their book entitled Connected: the Surprising Power of Our Social Networks and How They Shape Our Lives, Nicholas Christakis and James Fowler explore the science of social networks and its role in shaping lives. They combine traditions of social psychology and sociology with the new fields of neurosciences, genetic studies, and cyberspace to explore the role of networks, links, and paths in explaining the ways we learn and grow (Christakis and Fowler 2009). Christakis and Fowler suggest that (1) people are "connected" creatures, (2) there is a phenomenon (which they call a "contagion") of the spread and flow of information and attitudes flowing across network lines, (3) there is "a homophilic predisposition" to link with people who resemble us or whom we think we would like to be, and (4) networks can develop frameworks that attain lives of their own. Christakis and Fowler indicate that one of the ways we understand who we are is by experiencing ourselves in the mirror of people with whom we connect. These links have many degrees of separation, and ultimately our networks transcend our immediate contacts. A network community is a framework that can shape people and personality.

The notion of connectedness is not new to Jewish civilization. As a minority group living among larger groupings, Jews were invested in 
creating local and trans-geographical links with fellow Jews. This point is implied in popular interpretations of the talmudic phrase "every Israelite is responsible one for the other" (Babylonian Talmud; 39a) as meaning that there is a link and mutual responsibility between Jews over time and place. If one of the ways people learn how to be happy is by associating with happy people, one of the ways young Jews might be more Israel-connected is if they were to be in social networks of positively Israel-connected peers. The scaffolding of this Israel-connected process over the years of child's life (family albums, Skype, family trips, youth trips, learning Hebrew, youth retreats) is a worthy investment, whose outcomes will take time, but which is attainable and verifiable.

\section{Virtual Communities}

An important exemplar of contemporary connectedness is the "virtual community" - a group of people sharing common interests, ideas, and feelings over the Internet, which is made possible by the cyberspace revolution (Thomas and Brown 2011). The world of children, youth, young adults, and all people has dramatically expanded today to encompass virtual communities or digital networks. In a study of social media participation by youth and young adults, Mizuko Eto and colleagues researched the significance of the new technology for peer groupings, resulting in the creation of a tripartite typology of participation in social media (Eto 2011). The first level is called "hanging out"-becoming familiar with being with others in spaces mediated by digital technology. This level is not simply technical, but also social, and involves the process of building social identity. The second level is "messing around" which encompasses finding out more about, and experimenting with, one's personal identity on social media. This level is about beginning to explore topics of personal interest and discover them in a self-driven way. The third level is "geeking out" which means total comfort in using media in intense, autonomous, and interest-driven ways. It is a sense of embodiment and comfort in esoteric knowledge and personal interests in like-minded communities. Hanging out, messing around, and geeking out may sound like off-putting qualities, but they can open new doorways to access virtual Israel. Imagine the possibilities for shared communities of young Israeli and North American youth "hanging out" and talking about their day, their siblings, school work, parents, friends, love, loneliness, nothingness - and oh yes, also holidays and "Jewish stuff". 


\section{Language and Popular Culture}

Studies in linguistics, culture studies, and identity suggest significant connections between the concepts of mind, self, society, and identity (Duranti 2004). The nascent Zionist movement was deeply rooted in the culturalist notion of the centrality of language to national aspirations and personal identity (Alter 1994; Schiff 1997). There are voices in the contemporary American Jewish life that bemoan the abandonment of a culture of spoken Hebrew in American Jewish life and education and its replacement with a "ritual Hebrew" mainly taught for reading prayers or reciting bar/bat mitzvah portions (Sagarin 2015). Advocates of the Hebrew-asculture approach cite instructive counter examples of Hebraic cultures in contemporary pre-schools, suburban public high schools in Chicago, day schools and community life in Latin-American countries, and in Jewish summer camps in mid-twentieth-century America (Mintz 1993). A new view of Hebrew might constitute an important cultural change for Israel education.

Music and art in pop culture are powerful resources for presenting the pulse and heartbeat of people (Toran 2015). They express voices, images, and stories in a way that speaks to the young and to people of all ages. Analysts of contemporary youth culture cite these spheres, particularly music, as the lingua franca of contemporary youth. ${ }^{2}$ The use of visual art, literature, poetry, film, and the music of Israel provides educators with an accessible entry point to contemporary Israeli society and particularly to the world of its youth. Contemporary Israel is a veritable toy store of multiple forms of modern sounds, sights, foods, and people. This side of Israel has often been eclipsed by black and white newspaper photographs or 30-second television sound bites (which, indeed, are a part of contemporary Israel); however, even in the complicated reality called daily life in Israel, music, street life, attire, junk food, pop music, and graffiti connect one to the overall empire of contemporary youth (Glidden 2010).

\section{OEUVRES AND RituAls}

Jerome Bruner cites the French cultural psychologist Ignace Meyerson who suggested that the main function of all collective cultural activity is to produce oeuvres — works (Bruner 1990). Meyerson's point was that cultures create objects or artifacts that reveal values and become expressions of core ideals. They help create communities, serve as sources of pride, 
and affirm values. Oeuvres encompass pop culture-the golden arches, or a half-eaten apple-as well as works of fine art and creativity; Meyerson believed that creating oeuvres and experiencing them were important for the young.

Rituals of Jewish life are important oeuvres of the Jewish people, and many of them have Israel woven into their fiber. For some, these oeuvres are divine commandment, and for others they are cultural mores; however, there is little doubt of their place in the Jewish mindset. These oenvres, in fact, constitute a central preoccupation of most Jewish educational frameworks. However, the teaching of these rituals often does not overtly delineate their Israel-related motifs. The arks in synagogues typically face in the direction of Jerusalem, and many a young 13-year-old boy or 12-year-old girl has stood in the front of that ark on the day of their bar or bat mitzvah. The movie theater in a suburban neighborhood is likely to have a sign referring to an upcoming Israeli film festival. The Israeli basketball team plays exhibition games with NBA teams. These presences of Israel surface in the everyday life of the young, without always being apparent. Israeli artifacts are part of the general landscape, inhabited by a significant number of young North American Jews. These works are part of their "life space" even if not verbalized.

\section{ThE TRIP}

The first trip to Israel was that of Abraham from the Land of Canaan. From that time on, Jews have been the quintessential travelers, and the trip to Israel has been the primal metaphor of the traveling trait (Johnson 1987). In the twentieth century, the metaphor became a reality as millions of Jews traveled to Israel to live there. With the establishment of the state, educational travel to Israel for youth from abroad began to increase, and by the 1980s it had become a dynamic, if relatively modest, form of informal Jewish education. By that time, the educational value of the Israel trip was recognized, as educators adapted the phrase "the Israel experience" to describe such educational travel for teens. ${ }^{3}$ At the very end of the twentieth century, world Jewry and the State of Israel embarked on an effort called Birthright Israel to bring adolescents and young adults to Israel for an intensive ten-day educational program. (Saxe and Chazan 2008; Kellner 2012). This program was to constitute a major paradigm shift in American Jewish life, with more than half million young Jews having participated in a variegated 
program of Israel experience educational programs. Within a relatively short time, it is likely that for the first time since the destruction of the second Temple, the majority of the Jews of the world will have visited Israel. It is increasingly clear that one cannot conceive of an Israel education, which does not include an Israel experience. Indeed, if there is one facet of Israel education that has proven itself, it is that the power of an effective Israel experience is unmatched and irreplaceable. ${ }^{4}$ It is only logical that Israel education without an experience in Israel at some point is only a partial activity.

The power of the actual experience in Israel is related, among other things, to Israel being a totally immersive culture. Embracing real-life experiences and the multiple expressions of Jewishness that exist both in Israel and in Jewish life today is paramount. Modern Israel encompasses the panorama of narratives from the biblical Promised Land to postmodern contemporary society that we discussed in Chap. 2. In Israel, Abraham, Moses, Hosea, Judah the Maccabee, Maimonides, Herzl, Ahad Ha'am, Golda Meir, and David Ben-Gurion are not only street names, but also figures who still "live" there and their "voices" are heard daily. Indeed, the Israeli experience provides a direct linkage to a rich heritage and a living culture. The power of this meeting is enhanced by being deeply experiential, sensual, and people-centered.

There are many ways to see Israel-with a Fodor's@ Guidebook, a camera, the Bible, a prayer book, or the latest edition of The New York Times. ${ }^{5}$ The person-centered approach obviously implies maximizing the direct encounter and minimizing mediated framings. It aims to facilitate a dialogue between person and place in which both speak to each other. Young travelers come to the Western Wall to speak to it, and the Wall wants to talk to them. The art of enabling encounter is a delicate one; sometimes in order to facilitate a direct interaction, it is necessary to engage in a certain degree of framing (or what is denoted as "pre-conditions of education") so that the encounter can actually happen. There are situations in which a totally unmediated dynamic can sometimes actually prevent, rather than enable, genuine experience. The art of framing is the ability to enable the dialogue to take place, and not to impose a specific landscape on the actual moment. The actual implementation of Israel trips is a fine art, which has proven to be one of the unique achievements of American Jewish education. Indeed, one might well suggest that this aspect has been one of the most professional and sophisticated of contemporary forms of Jewish education. 


\section{RELATING AND RELATIONSHIPS}

The emergence of the field of Israel educational travel was accompanied by diverse pedagogies and methodologies. One of the more creative innovations in the field was pioneered by a young Jewish educator named Anne Lanski, who believed that visiting Israel was more than seeing ancient arches or tombs. It also (and, perhaps, mainly) involved interacting with real people who laugh, cry, and talk. Her thinking was initially encapsulated in the Hebrew word mifgash which literally means "meeting" and was used to refer to interactive programming between Israeli and overseas youth as part of the Israel experience. Over time, and particularly with the advent of Birthright Israel, mifgash became a fairly mainstream component of educational travel. On Birthright Israel trips, Israeli participants spend 5-10 days of the 10-day birthright trip as equal participants (Saxe and Chazan 2008). At a certain point, Lanski felt that while the mifgash idea was powerful, it had become too linked to being understood as a "program" rather than as an educational and heuristic process (Lanski et al. 2015). Consequently, Lanski and colleagues have expanded their original thinking of encounter into a prioritization of what they now call "relating and relationships" which they define as building meaningful and lasting interactions that become the connections that sustain, nurture, and enrich us individually and collectively. They suggest that the relationship building process begins and ends with the participants and their inner world, and then moves toward the collective. This practical pedagogy reflects a language of the dialogical that Martin Buber was to use in the twentieth-century theology and education. Buber used such phrases as "all real life is meeting" and "all actual life is an encounter" (Buber 1958). In terms of the Israel experience, this dialogic approach suggested the perspective of Israel rooted not only in holy sites or historical ruins, but also on normal people buying fruits and vegetables for their family. ${ }^{6}$

\section{The Educator}

For many people, the educator is the key factor in education. Whether one accepts this generalization or not, it is clear that educators play a central role in the elaborate process of Israel education that we have described in the previous two chapters. Indeed, our past discussions point to certain core values, aptitudes, and tasks of an Israeli educator. 
The first necessary skill set is relationship building - the ability to be a connector between the student and the idea of Israel. This task is a process that encompasses listening skills that make the student feel comfortable to speak, questioning skills that are aimed at initiating conversation, sensitivity skills that create a comfortable personal and group setting, and the personal trait of humility (what David Brooks calls "epistemological modesty" (Brooks 1999).

A second skill set is facilitation of discussion between the student and texts which constitute Land of Israel narratives. These texts need to be studied in a way that makes their analysis and deconstruction communicative to the student and helps him/her internalize their diverse meanings. This skill set requires familiarity with core texts and the ability to guide students through a careful literal and then interpretive reading and discussion of the positions presented in these texts. The orientation of the educator in this instance is personalization, meaning-making, and big ideas, and, in this instance, is less focused on halakhic, and decoding skills (Holtz; and Levisohn 2013).

A third skill set is an approach to Jewish rituals—prayer, holidays, home observance, grace after meals - which, among other foci, helps the young discover the pervasive Israeli presence in these areas of Jewish life. A core blessing in the grace after meals refers to the rebuilding of Jerusalem. The prayer cited when the Torah scroll is removed from the ark announces that the Torah "came forth from Zion, and the word of Lord from Jerusalem" (Isaiah 2:3). At the end of a wedding ceremony, a glass is broken by the groom as a remembrance of the fallen Temple in Jerusalem. These rituals are both moments of piety and manifestation of the presence of Israel in everyday Jewish life.

The fourth skill set is what we have in this chapter called culture building. The pedagogy of culture building includes understanding and structuring of physical space, use of music and art, literature Israeli peers, travel to Israel posters, and regalia of Israel. This skill set is rooted in general cultural sensibility and sensitivity which, while having specific Israeli content, has elements of the mindsets and perspectives of a Steven Spielberg, Zubin Mehta, and Cirque du Soleil.

All of these are critical, but the key skill set of the Israel educator is actually none of these. It is about something much deeper which is at the core. It is about the relationship within or the landscape of the teacher's inner soul. This vision belongs to Parker Palmer-a shaping contemporary figure in advocating for the primacy of the teacher in a human-focused 
education. Palmer's life work speaks directly to our discussion of Israel education. He begins with the notion of the inner landscape of the teacher's soul which he regards as the starting point and fulcrum of pedagogy. He speaks about the courage needed to teach from within-of teaching from that spot where mind and heart come together to shape a total human being. For Palmer, teaching is not about the "what" or the "how" of education; rather, it is about the "why" and the "who". His chief pedagogic tool is the heart of a teacher-and the identity and integrity which the teacher utilizes in his or her work. In contrast to some approaches to teaching which call for the distancing of self from the teaching content and act, Palmer says that this is where teaching begins. Teaching is not about transmission of facts-we have computers that can do that. It is rather about the re-shaping of character-and there is no technology that do that. How one learns about good character is by being near people of positive character. Palmer's teacher is not a preacher who "transmits", but an instructor who feels, thinks, questions, achieves, and sometimes fails - all of which are traits of character. Palmer's teacher is a living breathing human being who utilizes the totality of mind and heart as his core pedagogical technique.

There is probably is no topic that is more fitting for a Palmer teacher than Israel. ${ }^{7}$ Israel education calls for educators who model commitment, thinking, feeling, doubt, questioning, joy, sadness, certainty, and epistemological modesty. A subject as beloved, complicated, engaging, and confusing as Israel deserves a Parker Palmer teacher. Being an Israel educator has sometimes been regarded as a complicated endeavor in this period of the contemporary State of Israel. ${ }^{8}$ The establishment and achievements of the contemporary state are observable. Its importance for world Jewry is palpable. However, some dynamics related to contemporary Israel, such as the geo-political conflict, religion and democracy, and the use of power have become problematic issues for educators. Ultimately, the issue is not specific to Israel education; it is about the challenge of teaching topics, places, and histories that are fraught with value complexity. The Bible is a document of great majesty; yet, there are sections that are fraught not just with moral dilemmas but also with instances of moral behaviors, which seem incomprehensible. This dilemma is not limited to parochial education. The teachings of American history encompass grand moments of core American values and at the same significant examples of moral deficiency (Ragland and Woestman, 2009). 
The answer to the issue of teaching a topic which includes ambiguity for the teacher, returns to our discussion in chapters 1 and 2: what is the aim, what is the subject, and what kind of education is Israel education? The aim of Israel education is relationship; the subject is the person; and the domain is value education. Whether one is teaching American history, ethnic heritage, or contemporary Israel, one has entered arenas that are about values and value choices. Ours is not to preach the right or the wrong; it is to develop the ability to negotiate the complex landscape known as life. The ability to negotiate this landscape is one the core missions of education; it is in this sense that Palmer speaks about the courage to teach. The challenge raised in the contemporary discussion of Israel is about the larger issues of conflict and decisions. The world in which we live includes dissonance and conflict. The cultures we live in do not fit together like the perfect jigsaw puzzle. There are sometimes pieces that take a long time to put in the right spot; sometimes pieces get lost; sometimes you just don't have any more patience and you break up the pieces out of frustration-or pleasure. Our task in Israel education is very much related to helping our charges through the deeply engaging, and also periodically complicating, pathways that constitute an Israeli relationship. This task encompasses dealing with difficult issues in a way that is developmentally appropriate, while also allowing voices of assent and dissent to be heard. One of the virtues of contemporary Israeli life is the presence of diverse voices, and they should find their place in the life and education of our young at the opportune moments. Our task as educators is to be passionate about a culture of open dialogue of diverse opinions, policies, and perspectives. One of the ways that a person learns to be a choosing person is by being around people and educational settings that teach us that choice exists and how to deal with it. The pathways of Israel, old and new, are lined with past treasures and contemporary achievement, and along the way there have been, are, and always will be diverse side roads and sometimes even dead ends. Twenty-first-century life includes complexity and nuance. This is not a position of compromise or weakness or of compliance; this is the culture of the will to educate.

\section{The Woven TAPestry}

In these three chapters we have attempted to present a logical, clearly defined and articulated pattern approach to the contemporary topic of Israel education. But, truth be told, our tasks ultimately is that of the 
weaver. Our task encompasses presenting a vision, proposing an educational aim, delineating specific contents, proposing methodologies, creating cultures, and describing the role of the educator. The ultimate task is about weaving together a host of threads, some of which flow smoothly and some of which do not seem to connect. Durkheim exaggerated when he implied that educators are superheroes and so did Nietzsche and Freud when they indicated that ours is an impossible profession (Durkheim 1956; Nietzsche 2015; Britzman 2009). We are probably best seen as weavers of a tapestry, hosts of a well-orchestrated party of diverse guests, and master conductors of a symphony. Our mission is to enable the music of education to win out over the din of postmodern life.

\section{BIBLIOGRAPHY}

Alter, R. (1994). Hebrew and modernity. Bloomington: Indiana University Press. Print.

Bettelheim, Bruno. (1950). Love is Not Enough. Chicago: Free Press. Print.

Britzman, D. P. (2009). The very thought of education: Psychoanalysis and the impossible professions. Albany: State University of New York. Print.

Brooks, D. (1999). The social animal: The hidden sources of love, character, and achievement. New York: Random House, 2012. Print.

Brooks, David. (2011). The Social Animal: The Hidden Sources of Love, Character, and Achievement. New York: Random House. Print

Bruner, Jerome. (1997). The Culture of Education. Cambridge: Harvard UP. Print. Bruner, J. (1990). The culture of education. Cambridge, MA: Harvard University Press, 1996. Print.

Buber, M. (1958). I and thou. New York: Charles Scribner and Sons, 1970. Print.

Christakis, N. A., \& Fowler, J. H. (2009). Connected: The surprising power of our social networks and how they shape our lives. New York: Little, Brown. Print.

Duranti, Alessandro. (1997). Linguistic Anthropology. Cambridge: Cambridge University Press. Print.

Duranti, A. (2004). Linguistic anthropology. New York: Cambridge University Press, 1997. Print.

Durkheim, É. (1956). Education and sociology. Glencoe: Free Press. Print.

Eto, Mizuko. (2009). Hanging Out, Messing Around, and Geeking Out. Cambridge: MIT Press. Print.

Freud, S. (1962). Civilization and its discontents. New York: W.W. Norton. Print.

Glidden, Sarah and Clem Robins. (2010). How to Understand Israel in 60 Days or Less. New York: Vertigo/DC Comics. Print.

Goffman, E. (1960). Asylums: Essays on the social situation of mental patients and other inmates. New York: Anchor Books, 1961, Print. 
Goffman, Erving. (1961). Asylums: Essays on the Social Situation of Mental Patients and Other Inmates. New York: Anchor Books. Print.

Goitein, S. D. (1999). A Mediterranean society. Berkeley: University of California Press.

Holtz, B. (2013). A map of orientations to the teaching of Bible. In J. Levisohn, \& S. Fendrick (Eds.), Turn it and turn it again: Studies in the etching and learning of classical Jewish texts. Boston: Academic studies Press, 2023. Print.

Ito, M. (2011). Hanging out, messing around, and geeking out; Kids learning and living with new media. Cambridge, MA: MIT, 2010. Print.

Johnson, P. (1987). A history of the Jews. New York: Harper \& Row. Print.

Lanski, A., Stewart, A., \& Werchow, Y. (2015). Relating and relationships. The Aleph Bets of Israel education. N. pag. www.theicenter.org. The iCenter for Israel Education. Web.

Levisohn, J. (2013). What are the orientations to the teaching of Rabbinic literature? In Turn it and turn it again: Studies in the teaching and learning of classical texts. Boston: Academic Studies Press. Print.

Levisohn, Jon and Fendrick, Susan, editors. (2014). Turn It and Turn It Again: Studies in the Teaching and Learning of Clasisical Jewish Texts. Boston: Academic Studies Press. Print.

Mintz, A. L. (1993). Hebrew in America: Perspectives and prospects. Detroit: Wayne State University Press. Print.

Neill, A. S. (1970). Summerhill: For \& against. New York: Hart Pub. Print.

Nietzsche, Friedrich. (2015). Anti-Education: On the Future of Our Educational Institutions. New York: NYRB Classics. Print.

Peshkin, A. (1986). God's choice: The total world of a fundamentalist Christian school. Chicago: University of Chicago. Print.

Redl, F., \& Wineman, D. (1957). The aggressive child. Glencoe: Free. Print.

Sagarin, Lori. (2015). Modern Hebrew: Culture and Identity. The Alef Bet of Israel education. N. pag. www.theicenter.org. The iCenter for Israel Education. Web.

Sartre, J.-P. (1967). Existentialism and human emotions. New York: Philosophical Library. Print.

Saxe, L., \& Chazan, B. I. (2008). Ten days of birthright Israel: A journey in young adult identity. Waltham: Brandeis University Press. Print.

Schiff, Alvin. (1997). The Mystique of Hebrew. New York: Schreiber, Shengold Publishing. Print.

Soberman, M., \& Stewart, A. (2015). Experiencing Israel. In The Aleph Bet of Israel education. The iCenter Press: Northbrook. Print.

Thomas, D., \& Brown, J. S. (2011). A new culture of learning: Cultivating the imagination for a world of constant change. Lexington: CreateSpace. Print.

Toran, Vavi. (2015). Israeli Arts and Culture: the Ability to Engage. The Alef Bet of Israel education. N. pag. www.theicenter.org. The iCenter for Israel Education. Web. 


\section{Notes}

1. Some of these institutions are Bettelheim's Sonia Shankman Orthogenic School in Chicago, Redl and Wineman's Pioneer House in Detroit, Neil's Summerhill, and Peskin's Bethany Academy.

2. "The shift from stuff to experiences has had a profound impact on the soundtrack of Youth of the nation, as the popular center of gravity has seemingly shifted. Hip-hop, largely focused on messages of affluence and excess, is giving way to tech-fueled electronic dance material (EDM), largely rooted in experiences, love, and relationships-in some ways coming full circle to the sixties generation, but with a much different look and sound" (p. 37) (Matt Britton. YOUTH NATION: Building Remarkable Brands in a YouthDriven Culture. New York: Wiley, 2015).

3. In the last decades of the twentieth century, the educational trip to Israel has become known by the generic name "The Israel experience", reflecting an attempt to link this activity to John Dewey's ideas on experience and education, and this nomenclature entered the vocabulary of Jewish education. See: David Bryfman, editor. Experience and Jewish Education, Los Angeles Torah Aura, 2014.

4. There has been extensive research on Israel education over the past two decades. See Eric Cohen, Youth Tourism to Israel: Educational Experiences of the Diaspora (Channel View Publications, 2008). The Israeli Experience; Leonard Saxe et al. Birthright Israel (op. cit). Research on Israel in Jewish Education, Berman Center of Research, New York University.

5. The Israeli poet Yehuda Amichai wrote "he who loves Jerusalem by the tourist book or the prayer book is like one who loves a woman by a manual of sex positions" (Love of Jerusalem, Yehuda Amichai. Collected Poetry, New York: Harper and Row, 1988).

6. A poignant example of a thwarted encounter may be found in two autobiographies written on two sides of the same fence. One is the book Once Upon a Country by Palestinian intellectual Sari Nusseibeh, and the other is the book A Tale of Love and Darkness by Israeli writer Amos Oz. Both write almost identical books about childhood and youth, alleyways, people, and nostalgically growing up in Israel—one in Palestinian East Jerusalem and the other in Jewish West Jerusalem.

7. Parker Palmer's work has extended to an interest in issues related to the subject of this book. He has written an important Prelude to the Aleph Bet of Israel Education, 2nd Edition, which has been published by the iCenter for Israel Education (Professor Lee Shulman, former head of the Carnegie Foundation, and Professor Emeritus of Stanford University have written an equally engaging postlude). 
8. Two books that explore these complexities are Loving Israel: an Educational Guide for Liberal Zionism by Alex Sinclair and Israel Matters by Lisa Grant and Ezra Kopelowitz. Grant and Kopelowitz use the word "matters" to refer both to the noun "matters" meaning things or situations and to the verb "matters" meaning it is important or it is something we care about (Lisa Grant and Ezra Kopelowitz, Israel Matters: A 21st Century Paradigm for Jewish Education, Jerusalem: Center for Peoplehood Education, 2012).

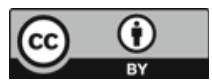

This chapter is distributed under the terms of the Creative Commons Attribution 4.0 International License (http://creativecommons.org/ licenses /by/4.0/), which permits use, duplication, adaptation, distribution and reproduction in any medium or format, as long as you give appropriate credit to the original author(s) and the source, provide a link to the Creative Commons license and indicate if changes were made.

The images or other third party material in this chapter are included in the work's Creative Commons license, unless indicated otherwise in the credit line; if such material is not included in the work's Creative Commons license and the respective action is not permitted by statutory regulation, users will need to obtain permission from the license holder to duplicate, adapt or reproduce the material. 